\title{
Pengaruh Komunikasi Internal dan Kerjasama Tim terhadap Kualitas Kerja Karyawan RSI Mabarrot MWC NU Bungah Gresik
}

\author{
Syifaun Nabilah Medika Putri ${ }^{1}$, Ahmad Khairul Hakim ${ }^{2}$ \\ ${ }^{1,2}$ Universitas Islam Negeri Sunan Ampel Surabaya \\ ${ }^{1}$ syifaunnabilahmp@gmail.com \\ ${ }^{2}$ khairul.hakim@uinsby.ac.id
}

\begin{tabular}{l}
\hline Article Info \\
\hline Article history: \\
Received 29 November 2021 \\
Accepted 7 Januari 2022 \\
Published 8 Januari 2022 \\
Page : 12 - 24 \\
\hline
\end{tabular}

Keyword:

Komunikasi Internal, Kerjasama Tim, Kualitas Kerja Karyawan

\begin{abstract}
This study aims to determine the effect of internal communication and teamwork on the quality of work of employees simultaneously or partially at RSI Mabarrot MWC $N U$ Bungah Gresik. The method used in this research is associative quantitative research. The researcher used multiple linear regression in answering the research objectives. This research is located at RSI Mabarrot MWC NU Bungah Gresik with a total of 87 respondents. The results of this study obtained test results on the formulation of the problem to prove that: First, there is a significant effect on internal communication and teamwork on the quality of employee work simultaneously. The two variables have a p value of $0.000<0.05$. Second, there is a significant effect on internal communication and teamwork on the quality of employees' work partially. Third, the variable of internal communication and teamwork on the quality of employee work is the $r$ value of 0.771 . The value of 0.771 indicates the value of a strong relationship given the independent variable and the dependent variable. This variable has a $p$ value of 0.000 . Fourth, internal communication has a correlation value of 0.637 , while teamwork has a correlation value of 0.719. Both of these variables indicate that internal communication and teamwork get a high or strong contribution. Fifth, the variable that has the highest value is teamwork, which is 0.719. Sixth, the regression model can be used as a predictor of employee performance in the future. This is due to the SEE value < standard deviation, which is $3.337<2.218$."
\end{abstract}

Penelitian ini bertujuan untuk mengetahui pengaruh komunikasi internal dan kerjasama tim terhadap kualitas kerja karyawan secara simultan maupun parsial di RSI Mabarrot MWC NU Bungah Gresik. Metode yang digunakan dalam penelitian ini yaitu penelitian kuantitatif jenis asosiatif. Peneliti menggunakan uji regresi linier berganda dalam menjawab tujuan penelitian. Penelitian ini berlokasi di RSI Mabarrot MWC NU Bungah Gresik dengan jumlah 87 responden. " Hasil penelitian ini memperoleh hasil uji pada rumusan masalah membuktikan, bahwa: Pertama, terdapat pengaruh yang signifikan pada komunikasi internal dan kerjasama tim terhadap kualitas kerja karyawan secara simultan. Dua variabel tersebut memiliki nilai p value 0,000 <0,05. Kedua, terdapat pengaruh signifikan pada komunikasi internal dan kerjasama tim terhadap kualitas kerja karyawan secara parsial. Ketiga, variabel komunikasi internal dan kerjasama tim terhadap kualitas kerja karyawan yaitu nilai $r$ 0,771. Nilai 0,771 menunjukkan nilai hubungan yang kuat diberikan variabel independen dan terhadap variabel dependen. Variabel tersebut memiliki nilai p value 0,000. Keempat, komunikasi internal memiliki nilai korelasi sebesar 0,637, sedangkan kerjasama tim memiliki nilai korelasi sejumlah 0,719. Kedua variabel tersebut menunjukkan, komunikasi internal dan kerjasama tim memperoleh hasil kontribusi yang tinggi atau kuat. Kelima, variabel yang memiliki nilai tertinggi adalah kerjasama tim, yaitu sebesar 0,719. Keenam, model regresi dapat digunakan sebagai prediksi kinerja karyawan di masa mendatang. Hal tersebut diakibatkan nilai SEE < standard deviation, yaitu 3,337 < 2,218."

Copyright (C) 2022 Journal Of Islamic Management. All rights reserved.

Editorial Office:

Program Studi Manajemen Dakwah, Fakultas Dakwah dan Komunikasi, UIN Sunan Ampel Surabaya.

Jl. Ahmad Yani 117 Surabaya, Jawa Timur, Indonesia.

Email: jim@uinsby.ac.id 


\section{Pendahuluan}

Ardana menjelaskan, bahwa "komunikasi internal merupakan penyampaian informasi kepada penerima informasi baik lisan maupun tertulis dalam lingkup organisasi". ${ }^{1}$ Zelko dan Dance dalam Arni Muhammad menyatakan, bahwa "komunikasi internal adalah komunikasi yang terjadi dalam lingkungan organisasi. Komunikasi tersebut berupa komunikasi atasan kepada bawahan, bawahan kepada atasan, dan karyawan sesama karyawan dalam satu tingkatannya. ${ }^{2}$ Komunikasi menciptakan kemudahan untuk mengendalikan perilaku anggota dengan berbagai cara. Komunikasi tersebut berhubungan dengan informasi tugas, arahan, penyampaian pendapat, penyamaan pandangan tujuan, dan lain sebagainya."

"Selain komunikasi, kerjasama tim merupakan wujud dari pengarahan dan pelaksanaan tujuan tertentu dalam organisasi. Pencapaian target organisasi sangat bergantung terhadap hasil dan kualitas kerja yang dihasilkan para anggota organisasi. Untuk mendapatkan hasil yang baik maka diperlukan pembagian kerja setiap individu yang terbentuk dalam kerjasama tim."

Menurut West dalam Imron menyatakan, bahwa "kerjasama tim adalah sekumpulan individu yang terbentuk dalam kelompok yang relatif kecil bekerja pada pekerjaan yang lebih jelas, tugas yang menantang, yang paling efisien dikerjakan jika dikerjakan bersama-sama dan

1 Komang Ardana, Manajemen Sumber Daya Manusia, (Yogyakarta: Graha Ilmu, 2012), 49.

${ }^{2}$ Muhammad Arni, Komunikasi Organisasi, (Bumi Aksara: Jakarta, 2005)

3 Imron, "Pengaruh Gaya Kepemimpinan, Kerjasama Tim, dan Budaya Organisasi terhadap Prestasi Kerja dan Dampaknya kepada Kinerja Pegawai", Jurnal Ekonomi dan Manejmen STIE Pertiba Pangkalpinang vol,. 5, no.1, 2019, 67.

${ }^{4}$ Putu Natalia K dan I Wayan Mudiartha U, "Pengaruh Kompensiasi. Motivasi, dan Lingkungan memiliki kepastian tujuan tim kerja yang harus saling bekerjasama dan saling tergantung untuk mencapai suatu tujuan. Anggota dalam tim memiliki peran yang berbeda dan memiliki wewenang yang diperlukan, otonomi dan sumber daya yang memungkinkan mereka untuk mencapai tujuan tim". 3

Kualitas kerja karyawan memiliki keterkaitan erat dengan manajemen dalam hal actuating. Yusuf dalam Putu Natalia K dan I Wayan Mudiartha U menjelaskan, bahwa "kualitas kerja merupakan kondisi dalam konsep perilaku organisasi yang terbentuk melalui usaha pihak manajemen untuk menaikkan taraf hidup pegawai yang dampaknya mampu menaikkan performa organisasi dan kualitas dalam bekerja. Terwujudnya kualitas dalam bekerja dapat dilakukan dengan beberapa cara yang dapat mendorong karyawan untuk bekerja secara maksimal". ${ }^{4}$

"Kualitas kerja seorang karyawan dapat diukur melalui kefektifan dan keefisiensi suatu pekerjaan yang dilakukan. Kualitas kerja tersebut mengacu pada kualitas sumber daya manusia yang handal, maka kualitas kerja akan berpengaruh dalam pencapaian tujuan organisasi. Flipo dalam Juwita Sari menjelaskan, bahwa meskipun setiap organisasi memiliki standar kualitas kerja pegawai, namun pada intinya efektivitas dan efisiensi menjadi acuan yang umum". ${ }^{5}$

"Pada era saat ini, sudah banyak yang melupakan pentingnya komunikasi dalam organisasi karena banyak yang lebih mementingkan menyelesaikan tanggung

Kerja terhadap Kualitas Kerja Karyawan PT. Delta Satria Dewata Denpasar", e-Jurnal Manajemen UNUD, 3-5.

5 Juwita sari, "Analisis Pengembangan dalam Meningkatkan Kualitas Kerja pada PT. Bank Muamalat Tbk Cabang Medan”, Skripsi, Fakultas Ekonomi Universitas Sumatera utara Medan, 1995, 28. 
jawab pekerjannya dibandingkan berkomunikasi dengan pihak-pihak yang ada di dalam organisasi. Diperlukannya kerjasama antar karyawan untuk mencapai kesejahteraan organisasi, jika organisasi mengalami penurunan salah satu faktor utama yaitu terjadinya komunikasi yang buruk yang terjadi dalam organisasi. Dalam hal ini, peneliti melakukan penelitian langsung di RSI Mabarrot MWC NU Bungah sebagai objek penelitian."

"RSI Mabarrot MWC NU Bungah Gresik merupakan suatau lembaga bisnis yang bergerak di bidang jasa dalam pelayanan kesehatan. RSI Mabarrot merupakan bagian dari Majelis Wakil Cabang Nahdlatul Ulama (MWC NU) Bungah yang mana merupakan organisasi sosial keagamaan dan kemasyarakatan yang berkedudukan di wilayah kecamatan Bungah. RSI Mabarrot termasuk rumah sakit swasta yang mana dikelola oleh dan untuk masyarakat khususnya masyarakat Nahdlatul Ulama."

"Dalam penelitian ini yang dimaksud dengan pengaruh komunikasi internal dan kerjasama tim terhadap kualitas kerja karyawan adalah bahwa komunikasi internal dapat memengaruhi kualitas kerja antara satu bagian organisai dengan bagian yang lain. Organisasi tidak akan bisa bertahan tanpa adanya komunikasi, khususnya komunikasi dalam lingkungan organisasi. Komunikasi yang baik akan melahirkan kondisi lingkungan organisasi yang menyenangkan dan kenyamanan. Sedangkan, komunikasi yang tidak baik akan menyebabkan kesalahpahaman, cekcok, ataupun perselisihan yang nantinya tidak akan menjadikan suatu keharmonisan. Dengan kata lain, adanya komunikasi internal bertujuan untuk menjalin hubungan yang

\footnotetext{
${ }^{6}$ Rahmad Restu Udayanto, "Pengaruh Komunikasi Internal dan Disiplin Kerja terhadap Kinerja Karyawan pada PT Cola-Cola", e-Journal Manajemen Bisma Universitas Pendidikan Ganesha, vol. 3, 2015, 3.
}

baik di lingkungan internal, agar tercapai kualitas kerja yang baik."

"Peneliti memilih komunikasi internal dan kerjasama tim untuk meningkatkan kualitas kerja karyawan RSI Mabarrot MWC NU Bungah Gresik. Komunikasi internal yang baik perlu dimaksimalkan dalam lingkup organisasi. Selain akan memperkokoh kekuatan organisasi. Komunikasi penting dalam penyampaian informasi berupa tugas, arahan, dan bimbingan antar anggota organisasi. Guna menghadapi persaingan, komunikasi internal dan kerjasama tim merupakan hal yang penting untuk mendukung pencapaian sasaran perusahaan dan tentunya didukung oleh kualitas kerja karyawan yang baik."

Dari latar belakang di atas, peneliti melakukan penelitian mengenai pengaruh komunikasi internal dan kerjasama tim dalam meningkatkan kualitas kerja karyawan RSI Mabarrot MWC NU Bungah, Gresik.

\section{KAJIAN PUSTAKA Komunikasi Internal}

Effendy dalam Rahmad Restu Udayanto menyatakan, bahwa "komunikasi merupakan suatu proses penyampaian pesan oleh komunikator kepada komunikan untuk membagikan informasi, mengubah sikap, dan pendapat baik secara langsung atau tidak langsung melalui media". 6 Sedangkan, Menurut Gibson dan Ivan dalam Dimas Okta Ardiansyah, "komunikasi adalah pemindahan informasi dan pemahaman baik simbol verbal maupun non verbal dari seseorang kepada seseorang"?

Sedangkan, "komunikasi internal merupakan proses pertukaran informasi dari komunikator ke komunikan baik

\footnotetext{
${ }^{7}$ Dimas Okta Ardiansyah, "Pengaruh Komunikasi terhadap Kinerja Karyawan dengan Dimediasi oleh Kepuasan Kerja" Jurnal Bisnis dan Manajemen, vol. 3 , no. $1,2016,18$.
} 
secara lisan, tertulis, ataupun media lainnya dalam lingkungan organisasi". 8 Sedangkan, menurut Zelko dan Dance dalam Arni menyatakan, bahwa "komunikasi internal adalah komunikasi yang terjadi dalam sebuah organisasi seperti komunikasi dari atasan kepada bawahan, komunikasi dari bawahan kepada atasan, dan komunikasi antar karyawan."

"Syarat untuk menciptakan komunikasi internal yang baik di antaranya adalah adanya kelancaran, nilai penting, kemanfaatan dalam berkomunikasi, informasi yang sesuai dengan kebutuhan, ketersediaan informasi yang berkenaan dengan tugas-tugas pekerjaan, kelengkapan media informasi, adanya pengakuan dari pihak perusahaan akan pentingnya suatu komunikasi, dan adanya timbal balik". 9

"Dalam perspektif Islam, komunikasi diperlukan sebagai jembatan pembentukan keharmonisan hubungan antar individu. Tanpa adanya komunikasi, kerawanan interaksi antar individu sulit untuk dihindari. Dengan demikian, komunikasi merupakan sesuatu yang esensinya penting dalam kehidupan. Menciptakan komunikasi yang baik dan berkualitas adalah sebuah keniscayaan". 10

"Komunikasi dalam Islam berhakikat berdakwah kepada manusia agar ke jalan yang memiliki nilai-nilai agama dan sosial budaya, yaitu menggunakan yang terdapat dalam AlQuran dan Hadis. Komunikasi Islam bukan hanya sekedar penyampaian pesan kepada audien atau komunikan, namun terjalinnya interkasi sosial yang normatif yang berisi

\footnotetext{
8 Komang Ardana, Manajemen Sumber Daya Manusia, (Yogyakarta: Graha Ilmu, 2012), 49.

${ }_{9}^{9}$ Muhammad Arni, Komunikasi Organisasi, (Bumi Aksara: Jakarta, 2005)

${ }^{10}$ Kusnadi, "Komunikasi dalam Al-Quran (Studi Analisis Komunikasi Interpersonal pada Kisah Nabi Ibrahim)", Intizar, Vol. 20, No. 2, 2014, 270

11 Imron, "Pengaruh Gaya Kepemimpinan, Kerjasama Tim, dan Budaya Organisasi terhadap
}

ajakan kebaikan. Bukan hanya untuk kebaikan dunia, namun bahagia di akhirat juga."

\section{Kerjasama Tim}

Poernomo

$$
\text { dalam }
$$

Imron

menjelaskan, bahwa "kerjasama tim merupakan suatu kegiatan yang dikelola dan dilaksanakan oleh sekelompok individu yang tergabung dalam suatu organisasi". ${ }^{11}$ Sedangkan, menurut Soekidjan dalam Nurwita, "kerjasama tim adalah pekerjaan yang dilakukan oleh sekelompok individu yang masing-masing memiliki keahlian. Sekelempok individu tersebut bertanggung jawab untuk pengambilan keputusan individu yang memegang suatu tujuan bersama. Selain itu, suatu tim bertemu untuk berkomunikasi, berbagi, dan mengonsolidasikan pengetahuan dari rencana yang dibuat karena keputusan di masa depan yang memengaruhi penentuan tindakan". 12

Dengan demikian, dapat disimpulkan bahwa "Kerja sama tim merupakan suatu pekerjaan yang dilakukan secara tim atau kelompok yang terorganisir dan dikelola dengan baik. Anggota dari suatu tim yang memiliki keahlian berbeda saling berkoodinasi dan saling ketergantungan demi mencapai suatu tujuan yang sama berupa suatu tugas dari pimpinan. Kerjasama tim akan menghasilkan pekerjaan yang efektif dan efisien dibandingkan dikerjakan secara perorangan. Semua individu dalam tim saling berkolaborasi menjadi satu sinergi yang kuat."

Pestasi Kerja dan danpaknya kepada Kinerja Pegawai", Jurnal Ekonomi dan Manajemen STIE Pertiba Pangkalpinang, vol. 5, no. 1, 2019, 67.

12 Nurwita, "Pengaruh Kerjasama Tim dan Gaya Kepemimpinan terhadap Kinerja Pegawai pada Kantor Polsek Medan Sunggal", Skripsi, Fakultas Ekonomi dan Bisnis Univ Medan Area, 2018, 2. 
Hariandja dalam Amanda Carolina Lakoy mengemukakan, bahwa ada tiga tipe tim yaitu ${ }^{13}$ :

1. "Problem Solving Team, yaitu tim yang dibentuk dalam tujuan menyelesaikan berbagai masalah yang muncul dalam upaya memperbaiki produktivitas."

2. "Self Managed Team, yaitu sebuah tim yang dibentuk untuk tujuan memperbaiki produktivitas suatu organisasi dengan mengatur atau memanajemen suatu pekerjaan."

3. "Cross Functional Team, yaitu sebuah tim yang dimaksudkann untuk melaksanakan beberapa tugas khusus."

Kerjasama tim atau teamwork dalam perspektif Islam bisa dikatakan saling tolong menolong, yaitu saling membantu antar sesama manusia dalam hal kebaikan. Tolong menolong merupakan salah satu kunci membangun kesuksesan dunia dan akhirat. Apabila suatu pekerjaan dikerjakan secara bersama-sama, maka akan muncul kebersamaan yang kuat.

\section{Kualitas Kerja Karyawan}

Russel dan Taylor dalam Widi Yuiani menyatakan, bahwa "kualitas merupakan bentuk totalitas tampilan dan karakteristik produk atau jasa dengan segenap kemampuan berusaha keras untuk memenuhi kebutuan tertentu". ${ }^{14}$

"Kualitas kerja merupakan salah satu hal yang penting dalam suatu organisasi. Kualitas kerja dipandang mampu untuk meningkatkan peran para karyawan terhadap organisasi. Kualitas kerja menurut Flipo dalam Juwita Sari adalah

13 Amanda Carolina Lakoy, "Pengaruh Komunikasi, Kerjasama Kelompok, dan Kreativitas terhadap Kinerja karyawan pada Hotel Aryaduta Manado”, Jurnal EMBA, vol. 3, no. 3, 2015, 10-11.

14 Widi Yuiani, "Pengaruh Kualitas Kerja, Pengawasan Kerja dan Kedisiplinan Kerja teradap Produktivitas Kerja Karyawan pada PT Pasar Raya Sri Ratu Semarang, Jurnal Fakultas Ekonomi dan Bisnis, 3. setiap organisasi pasti memiliki pandangan berbeda mengenai standar kualitas kerja karyawan, meskipun begitu efektivitas dan efisiensi tetap menjadi ukuran yang umum". ${ }^{15}$

Yusuf dalam Putu Natalia K dan I Wayan Mudiartha U memaparkan dalam penelitiannya, bahwa kualitas kerja merupakan kondisi dalam konsep perilaku organisasi yang terbentuk melalui usaha yang dilakukan oleh manajemen untuk menaikkan taraf hidup karyawan. Usaha tersebut diharapkan dapat meningkatkan kualitas kerja karyawan dan performa organisasi. ${ }^{16}$

Adapun kualitas kerja menurut Dessler dalam Putu Natalia K dan I Wayan Mudiartha $U$ bergantung pada beberapa faktor sebagai berikut: ${ }^{17}$

1. "Mendapat perlakuan adil, fair, dan sportif terhadap para karyawan."

2. "Mendapat kesempatan yang sama untuk mewujudkan diri dan menggunakan kemampuannya secara maksimal."

3. "Saling percaya dan membangun komunikasi yang baik antar pegawai dalam organisasi.'

4. "Mendapat kesempatan untuk berperan aktif dalam pengambilan keputusan yang berkenaan dalam pekerjaan karyawan."

5. "Mendapat kompensasi yang sesuai".

6. "Lingkungan yang baik, sehat, dan aman."

"Sebagaimana beberapa faktor yang menjadi pengaruh terhadap kualitas kerja karyawan salah satunya

15 Juwita sari, "Analisis Pengembangan dalam Meningkatkan Kualitas Kerja pada PT. Bank Muamalat Tbk Cabang Medan", Skripsi, Fakultas Ekonomi Universitas Sumatera utara Medan, 1995, 28.

16 Putu Natalia K dan I Wayan Mudiartha U, "Pengaruh Kompensiasi. Motivasi, dan Lingkungan Kerja terhadap Kualitas Kerja Karyawan PT. Delta Satria Dewata Denpasar", e-Jurnal Manajemen UNUD, 4.

${ }^{17}$ Ibid. 
adalah kenyamanan, penghargaan, dan kesempatan yang didapat di lingkungan kerja. Apabila terpenuhi faktor-faktor tersebut, secara tidak langsung karyawan akan memberikan kontribusi sebaik-baiknya terhadap organisasi."

\section{Pengaruh Komunikasi Internal dan Kerjasama Tim terhadap Kualitas Kerja Karyawan}

Setiap perusahaan dituntut untuk memaksimalkan kinerjanya dalam bekerjasama dengan orang lain untuk berbagai keperluan seperti keperluan bisnis, profesi, sosial dan berbagai macam keperluan lainnya. Mereka bekerjasama menentukan tujuan yang ingin dicapai menyusun rencana kerja, mengelola dan menjalankan operasi bisnis organisasinya. Untuk mewujudakn itu semua, maka diperlukan suatu kebersamaan dari anggotanya, yaitu pihak internal di dalam perusahaan. Apabila pihak-pihak internal di dalam perusahaan itu memiliki kerjasama yang baik, kompak, dan mengutamakan kepentingan perusahaan, maka hal ini akan menciptakan suatu iklim kerja yang kondusif dalam perusahaan dan sudah tentu kinerja perusahaan tersebut akan menjadi lebih baik pula.

\section{METODE PENELITIAN}

Pada penelitian ini, peneliti menggunakan pendekatan kuantitatif, Definisi "penelitian kuantitatif adalah mengemukakan fakta berupa angka-angka dengan memberikan pemaparan terhadap data kuantitatif setelah dilakukan tabulasi dan menentukan persentase." Jenis penelitiannya adalah asosiatif, yaitu "penelitian yang bersifat menanyakan hubungan antara dua variabel atau lebih." Asosiatif memiliki tiga bentuk hubungan, yaitu hubungan simetris, kausal, dan timbal balik. Apabila hal itu dilihat dari topik penelitian yang digunakan oleh peneliti mengarah pada hubungan kausal. "Hubungan kausal merupakan hubungan sebab akibat antara variabel independen terhadap variabel dependen". ${ }^{18}$

Adapun variabel dalam penelitian ini antara lain adalah sebagai berikut:

$\mathrm{X} 1$ : Komunikasi Internal

X2 : Kerjasama Tim

Y : Kualitas Kerja Karyawan

\section{Jenis dan Sumber Data}

Dalam penelitian ini menggunakan sumber data primer dan sekunder. "Data primer yang diperoleh dalam penelitian ini adalah jawaban responden melalui kuesioner yang disebarkan ke seluruh karyawan RSI Mabarrot MWC NU Bungah kemudian diolah dan dianalisis oleh peneliti. Sedangkan, data sekunder bersumber dari studi pustaka, dokumen yang berhubungan dengan kualitas kerja karyawan seperti buku-buku yang relevan dengan pembahasan, profil lembaga, website, daftar anggota pengurus, laporanlaporan lembaga di RSI Mabarrot MWC NU Bungah Gresik, serta sumber yang lain berupa hasil laporan penelitian yang masih ada hubungan dengan penelitian yang peneliti teliti."

\section{Teknik Pengumpulan Data}

Teknik pengumpulan data dalam penelitian ini menggunakan kuosioner, observasi dan dokumentasi dari beberapa sumber, seperti internet dan hasil olah data menggunakan SPSS 21 for windows.

\section{Uji Instrumen}

"Instrumen penelitian merupakan alat yang digunakan untuk mengukur nilainilai variabel yang akan diteliti, jumlah instrumen yang digunakan tergantung

18 Sugiono, Metode Penelitian Kuantitatif, Kualitatif, dan RnD. (Bandung: Alfabeta, 2011), 36 
jumlah variabel yang diteliti." Pada penelitian ini pengukuran yang dilakukan adalah menggunakan skala likert. "Skala likert merupakan skala yang digunakan untuk mengukur sikap, pendapat, persepsi seseorang atau kelompok tentang fenomena sosial."

\section{Uji Validitas}

"Validitas adalah suatu ukuran yang menunjukkan tingkat-tingkat kevalidan dan kesahihan suatu instrumen". ${ }^{19}$ Suatu instrumen dikatakan valid apabila mampu mengukur apa yang diinginkan serta dapat mengungkap data dari variabel yang diteliti secara tepat. Perhitungan dengan melakukan uji ini yaitu membandingkan pengambilan keputusan berupa $r$ tabel dengan $r$ hitung. $r$ tabel untuk degree of fredoom $(\mathrm{df})=\mathrm{n}-2$. N adalah jumlah sampel. Dari hasil uji validitas diperoleh $r$ hitung dalam instrumen penelitian yang digunakan semuanya memiliki nilai yang lebih besar atau berada diatas nilai kritis ( $\mathrm{r}$ tabel), sehingga dapat disimpulkan bahwa semua instrumen penelitian sudah valid.

\section{Uji Reliabilitas}

"Reliabilitas instrumen adalah hasil pengukuran yang dapat dipercaya. Uji reliabilitas instrumen dilakukan dengan tujuan untuk mengetahui konsistensi dari instrumen sebagai alat ukur, sehingga hasil suatu pengukuran dapat dipercaya". ${ }^{20}$ Peneliti menggunakan uji statistic Cronbach Alpha untuk mengukur realibilitas. Adapun nilai dari Alpha sebesar 0,05. Hal itu juga disebut dengan taraf signifikasi. Jika nilai Alpha lebih besar dari $\mathrm{r}$ kritis pada product moment, maka hasli dari uji instrument dinyatakn reliable. Nilai koefisien reliabilitas semua item instrumen tersebut lebih dari atau diatas 0,60, maka dapat disimpulkan

\footnotetext{
${ }^{19}$ Suharsimi Arikunto, Prosedur Penelitian Suatu Pendekatan Praktik, (Jakarta: Rineka Cipta, 2006), 158.
}

bahwa semua item instrumen atau angket yang digunakan sudah reliable.

\section{HASIL DAN PEMBAHASAN Karakteristik Responden}

Berdasarkan jenis kelamin responden didominasi oleh responden yang berjenis kelamin perempuan dari dengan jumlah sebesar 64 orang dengan presentase $73,6 \%$. Sedangkan, responden yang berjenis kelamin laki-laki berjumlah sekitar 23 orang dengan presentase $26,4 \%$.

Berdasarkan asal domisili responden didominasi oleh responden yang berasal dari domisili Gresik sebanyak 80 orang dengan presentase $92,0 \%$. Sedangkan, responden yang berasal dari domisili Lamongan sebanyak 4 orang dengan presentase $4,6 \%$, dan responden yang berasal dari luar domisili Gresik dan Lamongan sebanyak 3 orang dengan presentase $3,4 \%$.

Berdasarkan usia responden didominasi oleh karyawan yang berusia lebih dari 35 tahun sebanyak 34 orang dengan presentase 39,1\%. Sedangkan, responden yang berusia 20-25 tahun ada sekitar 21 orang dengan presentase $24,1 \%$, responden yang berusia 26-30 tahun sebanyak 19 orang dengan presentase $21,8 \%$, dan responden yang berusia $31-35$ tahun sebanyak 13 orang dengan presentase $14,9 \%$.

Berdasarkan status jabatan responden di dominasi oleh profesi perawat sebanyak 21 orang presentase $24,1 \%$. Sedangkan, untuk jabatan lainnya seperti dokter terdapat 11 orang dengan presentase $12,6 \%, 15$ Bidan dengan presentase $17,2 \%, 7$ bagian Farmasi dengan presentase $8,0 \%, 1$ bagian Kesehatan Lingkungan dengan presentase $1,1 \%, 5$ bagian Analis dengan presentase $5,7 \%, 11$ bagian Administrasi dengan presentase $12,6 \%, 14$ bagian Umum

\footnotetext{
${ }^{20}$ Sambas Ali Muhidin dan Maman Abdurahman, Analisis Korelasi, Regresi,dan Jalur, (Bandung: Pustaka Setia, 2009), 37.
} 
dengan presentase 16,1\%, 1 bagian Rekam Medis dengan presentase $1,1 \%$, dan terdapat 1 bagian Gizi Medis dengan presentase $1,1 \%$.

Dan berdasarkan masa jabatan menunjukkan didominasi oleh responden yang memiliki masa kerja antar 1-5 tahun dengan presentase $59,8 \%$ dan yang terendah memiliki masa kerja kurang dari 1 tahun dengan presentase $2,3 \%$.

\section{Analisis Data}

Peneliti melakukan uji asumsi klasik setelah melakukan uji validitas dan uji reabilitas. Uji asumsi klasik dilakukan dengan tujuan agar populasi terwakili oleh data sampel yang sudah diolah. Uji analisa statistic yang digunakan meliputi:

a. Uji Normalitas

Peneliti menggunakan kolmogrovsmirnov test yang memiliki taraf signifikan $>0,05$. Adapun hasil uji normalitas data memakai SPSS Versi 25.

Tabel di atas membuktikan, bahwa signifikansi variabel sebesar 0,200. Adapun taraf signifikansi kolmogrovsmirnov test sebesar 0,05. Hasil tabel di atas menunjukkan, bahwa 0,200 >0,05 artinya signifikansi variabel lebih besar daripada signifikansi 0,05. Kesimpulan yang dapat diperoleh adalah variabel komunikasi internal, kerjasama tim, dan kualitas kerja karyawan berdistribusi normal.

b. Uji Multikoliniaritas

"Uji multikoliniaritas adalah uji yang digunakan untuk mengetahui korelasi regresi antar variabel independen." Adapun hasil dari regresi yang ada pada multikoliniaritas yaitu jika besar nilai VIF $<10$ dan nilai tolerance $>0,10$.

Tabel 4.41

\begin{tabular}{|l|l|r|r|}
\hline \multicolumn{2}{|l|}{} & \multicolumn{2}{c|}{ Collinearity Statistics } \\
\cline { 3 - 4 } Model & Tolerance & \multicolumn{1}{c|}{ VIF } \\
\hline \multirow{3}{*}{1} & (Constant) & & \\
\cline { 2 - 4 } & Komunikasi Internal & .680 & 1.470 \\
\cline { 2 - 4 } & Kerjasama Tim & .680 & 1.470 \\
\hline
\end{tabular}

Adapun nilai variabel komunikasi internal adalah 0,680. Nilai tersebut lebih

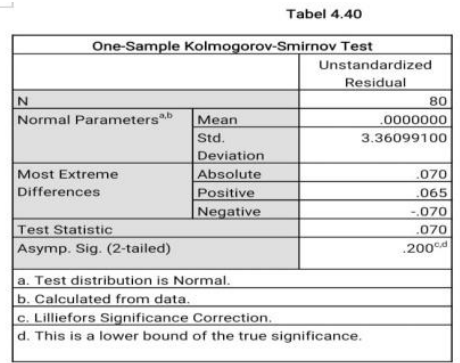

besar dari nilai 0,10 . Nilai VIF variabel komunikasi internal sebesar 1,470 dan lebih kecil dari 10. Nilai variabel kerjasama tim sebesar 0,680 lebih besar dari 0,10 dan nilai VIF sebesar 1,470 lebih kecil dari 10. Kesimpulan yang dapat diperoleh antar variabel independen tidak terjadi multikoliniaritas.

c. Uji Heteroskedastisitas

Adapun "uji heteroskedastisitas adalah alat uji yang digunakan untuk mengetahui adanya kesamaan atau perbedaan variasi dari residual pengamatan satu ke pengamatan yang lain." Peneliti menggunakan uji heteroskedastisitas glejser. Uji tersebut memiliki tujuan sebagai prediksi adanya heteroskedastisitas dengan melakukan regresi nilai absolut residual (Abs_Res) terhadap variabel independen. Apabila probablititasnya sig > 0,05, maka tidak terjadi heteroskedastisitas.

Tabel di atas memaparkan mengenai uji heteroskedastisitas dengan menggunakan gletser method. Variabel komunikasi internal memiliki nilai sig $0,222>0,05$. Adapun variabel kerjasama tim bernilai $>0,05$. Oleh karena itu, model regresi memiliki hasil tidak terjadi 
Tabel 4.42

\begin{tabular}{|l|l|l|}
\hline Variabel & Sig & Kesimpulan \\
\hline $\begin{array}{l}\text { Komunikasi } \\
\text { Internal }\end{array}$ & 0.222 & $\begin{array}{l}\text { Tidak terjadi } \\
\text { Heteroskedastisitas }\end{array}$ \\
\hline $\begin{array}{l}\text { Kerjasama } \\
\text { Tim }\end{array}$ & 0.997 & $\begin{array}{l}\text { Tidak terjadi } \\
\text { Heteroskedastisitas }\end{array}$ \\
\hline & & \\
\hline
\end{tabular}

heteroskedastisitas, sehingga dapat digunakan sebagai penelitian selanjutnya.

d. Uji Regresi Linier Berganda

Uji regresi linier berganda merupakan suatu alat uji yang memiliki kegunaan untuk melakukan pengujian terhadap hubungan linier antara beberapa variabel independen dan variabel dependen. Uji ini memiliki fungsi memprediksi nilai variabel dependen berdasarkan variabel independen. Adapun hasil uji regresi lier berganda sebagai berikut:

\section{1) Tabel Descriptive}

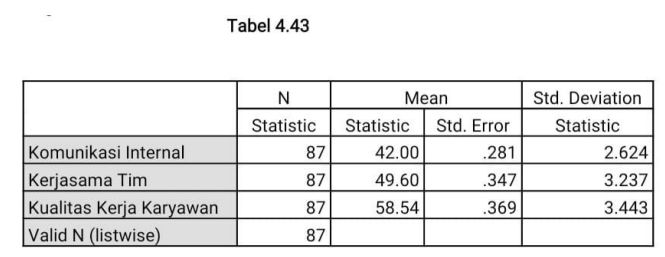

Menurut tabel di atas jumlah responden sebanyak 87 memperoleh hasil mean (rata-rata) dan simpang baku dari masing-masing variabel. Mean dari variabel komunikasi internal sebesar 42,00. Sedangkan mean dari variabel kerjasama tim sebesar 49,60. Mean dari variabel kualitas kerja karyawan sebesar 58,54. Adapun nilai dari simpangan baku variabel komunikasi internal sebesar 2,624. Simpangan baku dari variabel kerjasama tim sebesar 3,237 dan simpangan baku dari variabel kualitas kerja karyawan sebesar 3,443.

\section{2) Tabel Correlation}

Tabel tersebut menunjukkan informasi mengenai nilai hubungan antar variabel. Adapun nilai korelasi variabel komunikasi internal dengan variabel kualitas kerja karyawan sebesar 0,637 dengan $p$ value (signifikan) sebesar 0,000.
Oleh karena itu dapat dibuktikan, bahwa terdapat korelasi yang kuat atau tinggi. Adapun korelasi tersebut signifikan, karena $p$ value lebih kecil dari 0,05 . Nilai variabel kerjasama tim dengan variabel kualitas kerja karyawan sebesar 0,719 dengan $p$ value (signifikan) sebesar 0,000. Sehingga hal tersebut dinyatakan terdapat

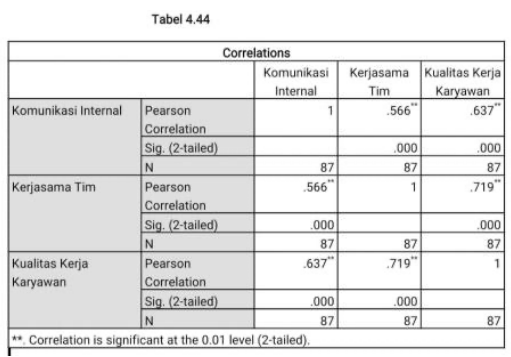

korelasi yang kuat atau tinggi. Adapun hasil korelasi tersebut signifikan, karena $\mathrm{p}$ value lebih kecil dari 0,05.

\section{3) Tabel Variabel Entered/Removed}

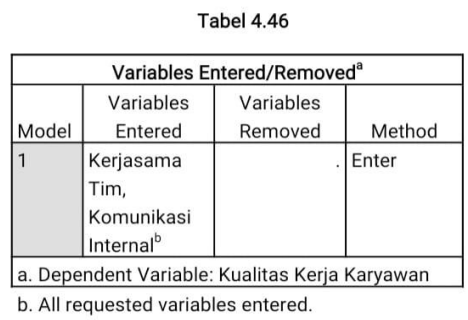

Tabel ini menunjukkan, bahwa semua variabel dalam penelitian ini yang meliputi komunikasi internal, kerjasama tim, dan kualitas kerja karyawan telah dilakukan dalam pengolahan data.

\section{4) Tabel Summary}

Tabel "Model Summary" membuktikan mengenai nilai $\mathrm{R}$. Berdasarkan nilai $\mathrm{R}$ tersebut dapat diketahui, bahwa koefisien regresi regresi antar variabel penelitian yang meliputi komunikasi internal, kerjasama tim, dan kualitas kerja karyawan sebesar 0,771. Adapun nilai R Square sebesar 0,595. Tingkat kontribusi R Square yaitu $0,595 \mathrm{x}$ $100 \%$. Hal tersebut membuktikan, bahwa variabel komunikasi internal (X1) dan kerjasama tim (X2) menunjukkan dampak yang terjadi terhadap kualitas kerja 


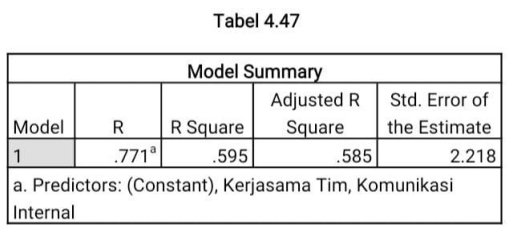

karyawan sebagai variabel $\mathrm{Y}$ yaitu 59,5\% dan 49,5\% dipengaruhi faktor lain.

5) Tabel Standard Error of Estimate

\begin{tabular}{|c|c|c|c|c|}
\hline \multicolumn{5}{|c|}{ Model Summary } \\
\hline Model & $\mathrm{R}$ & R Square & $\begin{array}{c}\text { Adjusted R } \\
\text { Square } \\
\end{array}$ & $\begin{array}{l}\begin{array}{l}\text { Std. Error of } \\
\text { the Estimate }\end{array}\end{array}$ \\
\hline 1 & $.771^{\mathrm{a}}$ & \begin{tabular}{|r|}
.595 \\
\end{tabular} & .585 & 2.218 \\
\hline
\end{tabular}

Tabel Standard Error of Estimate (SEE) sebesar 2,218. Nilai dari tabel SEE berfungsi untuk menguji apakah model regresi dapat berfungsi dengan baik untuk dijadikan sebagai prediktor. Nilai SEE terlebih dahulu dibandingkan dengan simpangan baku.

Jika nilai SEE lebih kecil dari simpangan baku, maka model regresi ini dapat digunakan sebagai prediktor kualitas kerja karyawan. Adapun nilai simpangan baku sebesar 3,443. Hasil tersebut menyatakan, bahwa nilai $\mathrm{SEE}<$ simpangan baku. Oleh karena itu model regresi ini dapat digunakan sebagai prediktor kualitas kerja karyawan.

\section{6) Tabel Anova}

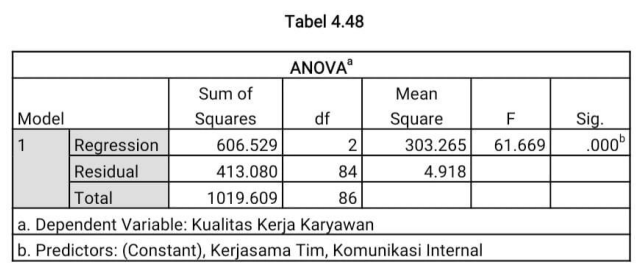

Tabel "Anova" memperkuat interpretasi, bahwa hubungan komunikasi internal, kerjasama tim, dan kualitas kerja karyawan bernilai signifikan. Nilai $F$ menjadi bukti hasil dari hubungan yang signifikan tersebut. Pada tabel di atas, nilai F sebesar 61,669 dengan melihat sig. 0,000 $<0,05$. Dengan demikian hubungan antar variabel tersebut dikatakan signifikan.

\section{7) Tabel Coefficients}

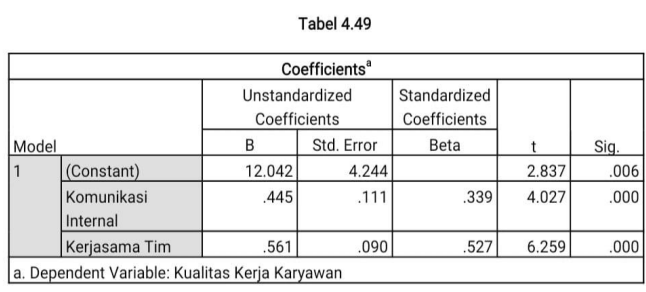

Tabel "Coefficients" menunjukkan persamaan regresi. Adapun rumus persamaan regresi sebagai berikut:

$$
\begin{aligned}
& \hat{Y}=a+b 1 \times 1+b 2 \times 2 \\
& \hat{Y}=a+b 1 \times 1+b 2 \times 2 \\
& \hat{Y}=12,042+0,445(0)+0,561 \\
& \hat{Y}=12,042
\end{aligned}
$$

Informasi tersebut menyatakan, bahwa jika komunikasi internal $(\mathrm{X} 1)=0$, kerjasama tim $(X 2)=0$, maka kulitas kerja karyawan sebesar 12,042.

\section{Pembahasan Hasil Penelitian}

Pengaruh Komunikasi Internal dan Kerjasama Tim Terhadap Kualitas Kerja Karyawan Secara Simultan

Adapun hasil dari tabel "Anova" menunjukkan, bahwa variabel independen memiliki pengaruh yang signifikan pada variabel dependen dengan $\mathrm{p}$ value sebesar $0,000<0,05$. Penjelasan tersebut berarti, bahwa komunikasi internal dan kerjasama tim berpengaruh terhadap kualitas kerja karyawan.

"Komunikasi internal dan kerjasama tim memengaruhi kualitas kerja karyawan. Hal tersebut ditunjukkan pada penjelasan yang diuraikan peneliti. Berdasarkan tabel Anova menunjukkan bahwa variabel independen di atas memiliki peran terhadap variabel dependen secara bersama-sama."

Apabila hasil pengujian antara komunikasi internal dan kerjasama tim terhadap kualitas kerja karyawan bernilai signifikan, maka uraian teori di atas membuktikan kesesuaian antara komunikasi internal dan kerjasama tim memiliki pengaruh terhadap kualitas kerja karyawan. 
Pengaruh Komunikasi Internal dan Kerjasama Tim Terhadap Kualitas Kerja Karyawan Secara Parsial

a. Pengaruh komunikasi internal terhadap kualitas kerja karyawan

Hasil tabel 4.44 "Correlation" menunjukkan, bahwa nilai $\mathrm{p}$ value sebesar $0,000<0,05$. Nilai tersebut menunjukkan, bahwa variabel komunikasi internal bernilai signifikan. Pemaparan tersebut sesuai dengan hipotesis $\mathrm{H} 0$ ditolak maka berarti signifikan. Sehingga variabel komunikasi internal berpengaruh terhadap kualitas kerja karyawan di RSI Mabarrot MWC NU Bungah Gresik.

b. Pengaruh kerjasama tim terhadap kualitas kerja karyawan

Berdasarkan tabel 4.44 "Correlation" dapat diketahui, bahwa nilai signifikan variabel kerjasama tim terhadap kualitas kerja karyawan memiliki pengaruh yang signifikan dengan nilai $\mathrm{p}$ value sebesar $0,000<0,05$. Hal tersebut menyatakan, bahwa H0 ditolak dan hasil signifikan. Dengan demikian ada pengaruh antara kerjasama tim dan kualitas kerja karyawan di RSI Mabarrot MWC NU Bungah Gresik.

Nilai hubungan antara komunikasi internal dan kerjasama tim terhadap kualitas kerja karyawan secara simultan.

"Komunikasi internal dan kerjasama tim memengaruhi terhadap kualitas kerja karyawan sebanyak 59,5\% (kontribusi sejumlah $0,595 \times 100 \%$ ). Nilai tersebut menunjukan nilai $59,5 \%$ dan sisanya sebesar $49,5 \%$ dipengaruhi oleh variabelvariabel lain. Dengan demikian, dapat ditarik kesimpulan terdapat nilai hubungan yang kuat."

Nilai hubungan antara komunikasi internal dan kerjasama tim terhadap kualitas kerja karyawan secara parsial.

a. Nilai hubungan antara komunikasi internal terhadap kualitas kerja karyawan
Berdasarkan tabel 4.44 tentang "Correlations" memberikan informasi hasil hubungan antar variabel komunikasi internal (X1) terhadap kualitas kerja karyawan (Y). Nilai korelasi komunikasi internal (X1) dengan kualitas kerja karyawan (Y) sebesar 0,637 dengan $p$ value (signifikan) sebesar 0,000. Oleh karena itu, variabel komunikasi internal memiliki nilai hubung yang tinggi dan signifikan, yaitu ( $p$ value $<0,05$ ) terhadap kualitas kerja karyawan RSI Mabarrot MWC NU Bungah Gresik.

"Nilai hasil tersebut diperkuat dengan tabel 4.45 mengenai kekuatan hubungan. Berdasarkan tabel tersebut jika nilai rentang antara 0,60 sampai 0,79 , maka dinyatakan tinggi atau kuat. Nilai hasil dari variabel komunikasi internal terhadap kualitas kerja karyawan adalah 0,637 yang bermakna kuat. Adapun variabel kualitas kerja karyawan dipengaruhi oleh komunikasi internal sebesar $63,7 \%$ dan $36,3 \%$ merupakan variabel lainnya yang memengaruhi variabel kualitas kerja k"aryawan.

b. Nilai hubungan antara kerjasama tim terhadap kualitas kerja karyawan

Tabel 4.44 "Correlations" menunjukkan hubungan variabel kerjasama tim (X2) terhadap kualitas kerja karyawan (Y). Nilai korelasi kerjasama tim (X2) dengan kualitas kerja karyawan (Y) sebanyak 0,719 dengan $p$ value (signifikan) sebesar 0,000 . Sehingga nilai variabel kerjasama tim adalah tinggi atau kuat terhadap kualitas kerja karyawan RSI Mabarrot MWC NU Bungah Gresik.

"Nilai hasil tersebut diperkuat oleh tabel 4.45 mengenai kekuatan hubungan. Berdasarkan tabel tersebut jika nilai rentang antara 0,60 sampai 0,79 yang berarti tinggi atau kuat. Nilai hasil dari variabel kerjasama tim terhadap kualitas kerja karyawan adalah 0,719 yang bermakna kuat."

"Hasil analisa data model statistik, variabel kerjasama tim dipengaruhi oleh 
kualitas kerja karyawan sejumlah 71,9\% dan sisanya sebesar $28,1 \%$ dipengaruhi oleh variabel lain. Dari uraian di atas, dapat ditarik kesimpulan bahwa variabel kerjasama tim memiliki pengaruh yang kuat terhadap kinerja karyawan RSI Mabarrot MWC NU Bungah Gresik.”

Nilai hubungan paling dominan antara komunikasi internal dan kerjasama tim tethadap kualitas kerja karyawan secara parsial

Berdasarkan tabel 4.44 "Correlation" memberikan informasi nilai korelasi variabel yang paling dominan pada kualitas kerja karyawan. Variabel komunikasi internal memiliki nilai sebesar 0,637 dengan nilai $p$ value 0,000 yang berarti korelasi yang tinggi. Nilai variabel kerjasama tim sebesar 0,719 dengan nilai $p$ value 0,000 . Hal tersebut menunjukkan korelasi yang tinggi atau kuat. Dengan demikian, nilai hubungan yang paling dominan yaitu variabel kerjasama tim terhadap kualitas kerja karyawan RSI Mabarrot MWC NU Bungah Gresik.

\section{Prediksi tingkat kualitas kerja karyawan dengan komunikasi internal dan kerjasama tim}

Berdasarkan hasil uji regresi linier berganda pada tabel 4.47 "Model Summary". Nilai yang diperoleh dari "Standard Error of Estimate" (SEE) sebesar 2,218. Nilai SEE memiliki berguna untuk menguji model regresi sudah berfungsi dengan baik atau belum sebagai prediktor.

Oleh karena itu, nilai SEE harus dibandingkan dengan nilai simpangan baku yang berjumlah 3,443. Nilai SEE ternyata lebih kecil dari simpangan baku, maka model regresi ini dapat digunakan sebagai prediktor kualitas kerja karyawan. Dengan demikian, model regresi ini dapat digunakan sebagai prediksi pada kualitas kerja karyawan di masa yang akan datang.

\section{KESIMPULAN}

Berdasarkan hasil analisis dan pembahasan oleh peneliti mengenai komunikasi interal dan kerjasama tim terhadap kualitas kerja karyawan RSI Mabarrot MWC NU Bungah Gresik, maka dapat diambil kesimpulan sebagai berikut:

1. "Terdapat pengaruh yang signifikan pada komunikasi internal dan kerjasama tim terhadap kualitas kerja karyawan secara simultan. Dua variabel tersebut memiliki nilai $p$ value $0,000<0,05$."

2. "Terdapat pengaruh signifikan pada komunikasi internal dan kerjasama tim terhadap kualitas kerja karyawan secara parsial."

3. "Variabel komunikasi internal dan kerjasama tim terhadap kualitas kerja karyawan yaitu nilai $r \quad 0,771$. Nilai 0,771 menunjukkan nilai hubungan yang kuat diberikan variabel independen dan terhadap variabel dependen. Variabel tersebut memiliki nilai $p$ value $0,000 . "$

4. "Komunikasi internal memiliki nilai korelasi sebesar 0,637, sedangkan kerjasama tim memiliki nilai korelasi sejumlah 0,719. Kedua variabel tersebut menunjukkan, komunikasi internal dan kerjasama tim memperoleh hasil kontribusi yang tinggi atau kuat."

5. "Variabel yang memiliki nilai tertinggi adalah kerjasama tim, yaitu sebesar 0,719."

6. "Model regresi dapat digunakan sebagai prediksi kinerja karyawan di masa mendatang. Hal tersebut diakibatkan nilai SEE < standard deviation, yaitu 3,337<2,218."

\section{DAFTAR PUSTAKA}

Amanda Carolina Lakoy, "Pengaruh Komunikasi, Kerjasama Kelompok, dan Kreativitas terhadap Kinerja karyawan pada Hotel Aryaduta 
Manado", Jurnal EMBA, vol. 3, no. 3, 2015

Dimas Okta Ardiansyah, "Pengaruh Komunikasi terhadap Kinerja Karyawan dengan Dimediasi oleh Kepuasan Kerja" Jurnal Bisnis dan Manajemen, vol. 3, no. 1, 2016

Imron, "Pengaruh Gaya Kepemimpinan, Kerjasama Tim, dan Budaya Organisasi terhadap Prestasi Kerja dan Dampaknya kepada Kinerja Pegawai", Jurnal Ekonomi dan Manejmen STIE Pertiba Pangkalpinang vol,. 5, no.1, 2019

Juwita sari, "Analisis Pengembangan dalam Meningkatkan Kualitas Kerja pada PT. Bank Muamalat Tbk Cabang Medan", Skripsi, Fakultas Ekonomi Universitas Sumatera utara Medan, 1995

Komang Ardana, Manajemen Sumber Daya Manusia, (Yogyakarta: Graha Ilmu, 2012)

Kusnadi, "Komunikasi dalam Al-Quran (Studi Analisis Komunikasi Interpersonal pada Kisah Nabi Ibrahim)", Intizar, Vol. 20, No. 2, 2014

Muhammad Arni, Komunikasi Organisasi, (Bumi Aksara: Jakarta, 2005)

Nurwita, "Pengaruh Kerjasama Tim dan Gaya Kepemimpinan terhadap Kinerja Pegawai pada Kantor Polsek Medan Sunggal", Skripsi, Fakultas Ekonomi dan Bisnis Univ Medan Area, 2018

Putu Natalia K dan I Wayan Mudiartha U, "Pengaruh Kompensiasi. Motivasi, dan Lingkungan Kerja terhadap Kualitas Kerja Karyawan PT. Delta Satria Dewata Denpasar", e-Jurnal Manajemen UNUD

Rahmad Restu Udayanto, "Pengaruh Komunikasi Internal dan Disiplin Kerja terhadap Kinerja Karyawan pada PT Cola-Cola”, e-Journal Manajemen Bisma Universitas Pendidikan Ganesha, vol. 3, 2015
Sambas Ali Muhidin dan Maman Abdurahman, Analisis Korelasi, Regresi,dan Jalur, (Bandung: Pustaka Setia, 2009)

Sugiono, Metode Penelitian Kuantitatif, Kualitatif, dan RnD. (Bandung: Alfabeta, 2011)

Suharsimi Arikunto, Prosedur Penelitian Suatu Pendekatan Praktik, (Jakarta: Rineka Cipta, 2006)

Widi Yuiani, "Pengaruh Kualitas Kerja, Pengawasan Kerja dan Kedisiplinan Kerja teradap Produktivitas Kerja Karyawan pada PT Pasar Raya Sri Ratu Semarang, Jurnal Fakultas Ekonomi dan Bisnis 